\title{
Decision Support System for Mining Land Clearing in Magelang Regency Using the Simple Attribute Rating Technique (SMART) Method
}

\author{
Gregorius Hugo Himawan \\ Faculty of Science and Technology, universitas Sanata Dharma, Indonesia
}

\begin{tabular}{|c|c|}
\hline ARTICLEINFO & ABSTRACT \\
\hline Article history: & \multirow{3}{*}{$\begin{array}{l}\text { Magelang Regency is a district located on the slopes of Moun } \\
\text { Merapi in the western region, this existence makes Magelang } \\
\text { Regency has potential in the field of mineral mining in the form o } \\
\text { sand and rock. The number of riots that occurred because of the } \\
\text { opening of the mine that was not in accordance with the provisions } \\
\text { of the Energy, Resources and Minerals Service made the candidates } \\
\text { for the mine opener confused in determining the place that was ir } \\
\text { accordance with the provisions of the service. Each prospective } \\
\text { mine opener has his own considerations in determining the location } \\
\text { This final project is made to help provide recommendations to } \\
\text { prospective mine openers in determining the location to be openec } \\
\text { by considering the distance from settlements, distance from the } \\
\text { highway, area, type of mine, and mine location. Decision Suppor } \\
\text { System was built using PHP and MySQL. User can select criteria to } \\
\text { compare each location. The method used to provide } \\
\text { recommendations is the Simple Multi Attribute Rating Technique } \\
\text { (SMART) based on the criteria selected by the user. The final resul } \\
\text { obtained is the recommended mine location based on the order o } \\
\text { the final scores of the compared mine sites. }\end{array}$} \\
\hline $\begin{array}{r}\text { Received Dec 23, } 2020 \\
\text { Revised Jan 10, } 2021 \\
\text { Accepted Jan 20, } 2021\end{array}$ & \\
\hline $\begin{array}{l}\text { SMART; } \\
\text { PHP; } \\
\text { MySQL. }\end{array}$ & \\
\hline
\end{tabular}

This is an open access article under the CC BY-NC license.

\section{Corresponding Author:}

Gregorius Hugo Himawan

Faculty of Science and Technology, universitas Sanata Dharma, Indonesia

E-mail: gregoriushugo19@gmail.com

\section{INTRODUCTION}

Magelang Regency is a district located on the western slopes of Mount Merapi, which makes Magelang Regency a fertile area and has abundant mining products from Mount Merapi material. This makes Magelang Regency has sand and rock material mines in several places on the slopes of Merapi and the banks of rivers that originate at Merapi.

The rapid development and the need for materials in the form of sand and rock which are known to have very good quality make this. The material mining sector in the form of sand and rock in Magelang Regency is one of the main commodities for regional income besides tourism. However, currently there are many illegal miners who do not have official mining permits and do not meet the criteria of the Regional Government. Illegal mining causes considerable losses because does not consider the location of the land to be mined, causing environmental damage to frequent clashes between residents and investors.

The selection of this mining area is a problem for potential investors because maybe the potential investors do not know the areas and most of the actors are new people who are engaged in this field. Problem solving for potential investors from the Department of Public Works and 
Energy and Mineral Resources of Magelang Regency only provides a one-dimensional map that is less interactive and less understood by potential investors.

Starting from the description above, the researcher is interested in making a decision support system for the selection of new mining areas using the SMART (Simple Multi Attribute Rating Technique) method which is integrated with a geographic information system so that it can provide information about mining areas located in Magelang Regency. The system will be equipped with a mining area search facility based on a certain area. It is hoped that the system can help and provide information for potential investors who want to know about the distribution area of the Mount Merapi material mining area and help recommend new places to open new mining areas based on the urban planning map of Magelang Regency.

\section{METHOD}

The data collection techniques used to obtain data on the Decision Support System for New Mining Land Opening in Magelang Regency are:

1. Interview

Interviews were conducted with the Department of Public Works, Energy, Mineral Resources of Magelang Regency as the relevant agency and several mine owners and local residents.

2. Literature review

The literature study was obtained from literature and other references in the form of internet browsing about the system to be made.

3. Definition of Scope

This stage includes various activities to formulate the problem and scope, followed by identifying possible problem solving and the feasibility of the system created.

4. Problem analysis

Problem analysis is defined as the decomposition of an information system with a view to identifying and evaluating a problem and obstacles that occur in the system and its needs so that it can be expected how to improve and develop it.

5. Needs Analysis

In this stage, data collection and data analysis are carried out, especially regarding the needs of users of this system. Assessment is carried out on the strengths and weaknesses of the previously applied work methods. Analysis of the system uses PIECES (Performance, Information, Economic, Control, Efficiency, Service) in order to obtain solutions to problems in the previous system.

6. Logical Design

Making a logical design of the Decision Support System for New Mining Land Opening in Magelang Regency includes designing database designs, making decomposition diagrams, and data flow diagrams.

\section{RESULTS AND DISCUSSIONS}

System testing is done by matching the results of calculations from the system with manual calculations to test the suitability of the system with the design that has been made. System testing is also done by randomly testing the system to 12 people, namely 10 users and 2 admins. After testing the users and admins were asked to fill out the questionnaire that was distributed to determine the success rate of the system from user observations.

1. Decision Making Process

The decision-making process uses the SMART method on mining data selected by general users. The selection process is carried out by searching for mines that match the general user search. General users can search for mining data and general users will select which mine is an alternative choice. For example, general users choose the location of Bedogan, Sawangan 
sub-district, Menayu, Muntilan sub-district, Tumpang, Sawangan sub-district, Gondosuli, Muntilan sub-district and Keningar, Dukun sub-district.

The steps for calculating using the SMART method are as follows:

a. Based on the example above, the alternative mining locations chosen by the general user are Bedogan, Sawangan sub-district, Menayu, Muntilan sub-district, Tumpang, Sawangan sub-district, Gondosuli, Muntilan sub-district and Keningar, Dukun sub-district.

b. The user selects the criteria to be used for decision making. This system has criteria for distance from settlements, distance from highways, area, mine location and type of mine.

Table 1.

Criteria data for each alternative

\begin{tabular}{|c|c|c|c|c|c|}
\hline & \\
\hline & $\begin{array}{c}\text { Sawangan } \\
\text { Bedogan }\end{array}$ & $\begin{array}{c}\text { Mena } \\
\text { Muntilan }\end{array}$ & $\begin{array}{c}\text { Overlapping } \\
\text { Sawangan } \\
\end{array}$ & Gondosuli & forehead \\
\hline Distance (m) & Very close & Very far & Near & Very close & Enough \\
\hline $\begin{array}{l}\text { Large } \\
\text { Highway Distance }\end{array}$ & 32 & $\begin{array}{c}6 \\
\text { Very close }\end{array}$ & $\begin{array}{c}12 \\
\text { Very close }\end{array}$ & Far $^{20}$ & $\begin{array}{c}14 \\
\text { Very far }\end{array}$ \\
\hline $\begin{array}{l}\text { Mine Type } \\
\text { Location }\end{array}$ & $\begin{array}{c}\text { Sand } \\
\text { River flow }\end{array}$ & $\begin{array}{c}\text { Sand } \\
\text { River flow }\end{array}$ & $\begin{array}{l}\text { Seplit Sand } \\
\text { River flow }\end{array}$ & $\begin{array}{l}\text { Seplit Sand } \\
\text { River Flow }\end{array}$ & $\begin{array}{l}\text { Seplit Sand } \\
\text { Empty land }\end{array}$ \\
\hline
\end{tabular}

c. The user assigns a goal weight factor for each criterion.

Table 2.

Criteria data for each alternative

\begin{tabular}{lll}
\hline Criteria & \multicolumn{1}{c}{ Goal Factor } & Weight \\
\hline distance $(\mathrm{m})$ & Maximizing Distance & 10 \\
Area (Hectares) & Maximizing Area & 10 \\
Highway Distance & Minimizing Distance From Highways & 9 \\
Mine Type & Maximizing the need for mine types & 6 \\
Location & Maximizing location presence & 6 \\
\hline
\end{tabular}

d. The system calculates the normalized goal weight factor by comparing the value of each goal weight factor with the total goal weight factor.

The weight normalization calculation for each objective factor is as follows:

Normalization of the weights of the objective factor to maximize

weight $=\frac{\text { goal factor maximizing distance }}{\text { total weight of objective factor }}$

Normalization of the objective factor weights to maximize area:

wight $=\frac{\text { objective factor maximizing area }}{\text { total weight of objective factor }}$

$=\frac{10}{41}=0.2439$

Normalization of the weights of the objective factors to minimize the distance from the highway: 


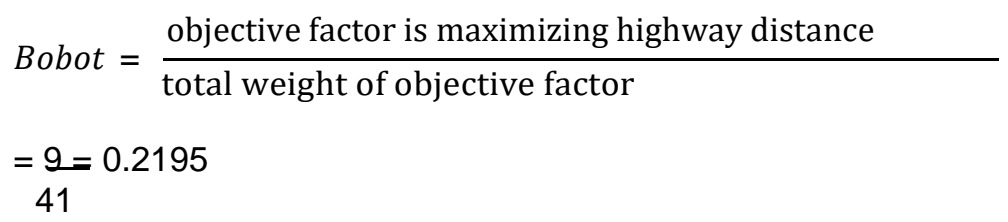

Normalization of factor weights to maximize mine type:

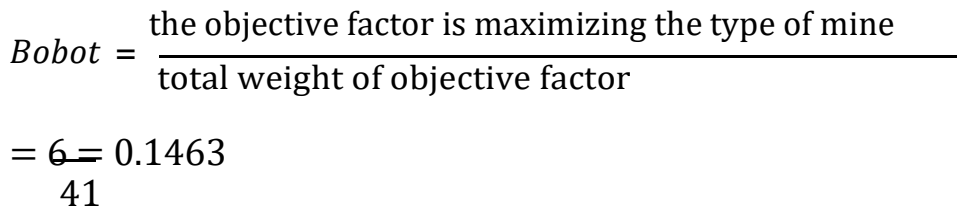

Table 3.

Normalization of objective factor weight

\begin{tabular}{lllc}
\hline Criteria & Goal Factor & Weight & Normalization \\
\hline distance $(\mathrm{m})$ & Maximizing Distance & 10 & 0.2439 \\
Area (Hectares) & Maximizing Area & 10 & 0.2439 \\
Highway Distance & Minimizing Distance from the highway & 9 & 0.2195 \\
Mine Type & Maximizing the need for mine types & 6 & 0.1463 \\
Location & Maximizing location presence & 6 & 0.1463 \\
& Total Weight & 41 &
\end{tabular}

e. The system converts the normalized value to the value of utility score between 0 to 1

Table 4.

Utility scores for the criteria of distance, area and distance of the highway

\begin{tabular}{cccccc}
$\begin{array}{c}\text { Score } \\
\text { normalization }\end{array}$ & 1 & 2 & 2 & 4 & 5 \\
utility score & 0 & 0.25 & 0.5 & 0.75 & 1 \\
\hline
\end{tabular}

Table 5.

Utility score for criteria of mine type and location

\begin{tabular}{lccc}
\hline normalizationscore & 1 & 2 & 3 \\
utility score & 0.33333 & 0.66667 & 1 \\
\hline
\end{tabular}

Table 6.

Utility score criteria

\begin{tabular}{cccccc} 
& Residential Distance & Large & walking distance & Mine Type & Location \\
\hline Bedogan & 0 & 1 & 0.25 & 1 & 1 \\
woo & 1 & 0 & 1 & 1 & 1 \\
Overlap & 0.25 & 0.25 & 1 & 0.66666667 & 1 \\
Gondosuli & 0 & 0.5 & 0.25 & 0.66666667 & 1 \\
forehead & 0.5 & 0.25 & 0 & 0.66666667 & 0.66666667 \\
\hline
\end{tabular}


f. The system will evaluate the final result of each alternative.

The steps are to multiply the utility score by normalizing the weight of the objective factor. Then add up to get the final score.

\section{CONCLUSION}

Based on the results of the design, development, and trial of the Decision Making Support System for New Mining Land Opening Using the Simple Multi Attribute Rating Technique (SMART) method, it can be concluded that the Magelang Regency Mining Land Clearing Decision Support System that was built is in accordance with the design and can run smoothly. good. The Decision Support System for Mining Land Clearing in Magelang Regency using the Simple Multi Attribute Rating Technique Method that was created was able to provide users with detailed mine location information. The Magelang Regency Mining Land Clearing Decision Support System with the Simple Multi Attribute Rating Technique method is able to provide recommendations in choosing a mine location based on the percentage of the calculated value according to the criteria required by the user. The Magelang Regency Mining Land Clearing Decision Support System with the Simple Multi Attribute Rating Technique has menus that are easy for users to understand. The Magelang Regency Mining Land Clearing Decision Support System with the Simple Multi Attribute Rating Technique method has steps that are easy for users to understand in finding mine site recommendations.

\section{References}

Daihani Dadan Umar, 2001. Komputerisasi Pengambilan Keputusan. Jakarta : Penerbit PT Elex Media Komputindo.

Kusrini, 2007. Konsep dan Aplikasi Sistem Pendukung Keputusan. Yogyakarta : Penerbit Andi.

Turban, Efraim, 1995. Decision Support Systems and Expert System. New York : Prentice-Hall.

Widhiyanta, Antonius Krisna, 2013. SISTEM PENDUKUNG PENGAMBILAN KEPUTUSA

PEMILIHAN SEPEDA MOTOR DENGAN METODE SMART. Yogyakarta: Skripsi USD.

Docherty, Tommy. 1978. The ABC of Soccer Sense Strategy \& Tactics today.

London: The Anchor Press Ltd,

Bangsbo, Jens dan Peitersen, Birger. 2008. Soccer Systems \& Strategies. United States: Human Kinetics

Bridle, Bob, dkk. 2011. Essential Soccer Skills. Newe York: Dorling Kindersley Dooley, Thomas dan Titz, Christian. 2011. Soccer-The 4-4-2 System. United

Kingdom: Meyer \& Meyer Sport

Scheunemann, Timo. 2008. Dasar-dasar Sepak Bola Modern Untuk Pemain dan Pelatih. Malang: Dioma

Nugroho, Robertus Adi, S.T., M.Eng. (2013). Materi kuliah Pengantar Pemrograman .NET dan Praktikum Pengantar Pemrograman .NET, Jurusan Teknik Informatika Universitas Sanata Dharma, Yogyakarta 